\title{
Kəskin qarın ağrısı, qəbzlik və ürək bulanması olan 85 yaşlı kişi xəstə.
}

Famil Babayev, $\mathrm{MD}^{1}, \mathrm{PhD}, \mathrm{MSc}$, Nabil Seyidov, $\mathrm{MD}^{1}, \mathrm{PhD}$, əlizadə C., $\mathrm{MD}^{1}$

${ }^{1}$ MediClub Hospital, Bakı, Azərbaycan Respublikası

\begin{abstract}
ABSTRAKT.
Təxminən 15 il əvvəl köndələn (yoğun) çənbər bağırsaq adenokarsinomasına görə iki etaplı yoğun bağırsaq rezeksiyası keçirmiş (əməliyyat sonrası böyük insizional yırtıq, ciddi adheziv proses əmələ gəlmişdir), habelə beş il əvvəl keçirdiyi işemik beyin insultundan sonra sağ tərəfli hemiplegiyası olan 74 yaşlı kişi xəstə 7 gün davam edən sancışəkilli qarın ağrısı, ürək bulanması, qazların və nəcisin xaric olmaması səbəbindən tibbi yardım həkimi tərəfindən müayinə olunmuş və bağırsaq keçməməzliyi diaqnozu ilə hospitalizasiya olunmuşdur. Aparılmış KT müayinəsində (per oral $40 \mathrm{ml}$ uroqrafin və venadaxili kontrastla (ultravist $100 \mathrm{ml}$ ) və kontrastsız) yoğun bağırsağın diametrinin genişlənməsi (xüsusilə də, kor bağırsağın nahiyəsində bağırsaq diametrinin $13 \mathrm{sm}$ olması) və hepatik fleksura nahiyyəsində mənfəzi obstruksiya edən törəmənin olması aşkar edilmişdir.
\end{abstract}

Daxil olarkən qan analizləri (elektrolitlər, qanın ümumi analizi, qidalanma statusunu təyin etmək üçün ümumi zülal və albumin səviyyəsi, koaquloqram, kreatinin, şəkər, qaraciyərin funksional paneli), EXOKQ, EKQ və digər müvafiq analizlər və diaqnostik görüntüləmə tədbirləri aparılmış, konservativ müalicə tədbirlərinə başlanılmış (həm də ehtimal edilən əməliyyatönü hazırığın tərkib hissəsi kimi), nazoqastral dekompressiv zond qoyulmuş, mərkəzi və periferik venoz kateterlər vasitəsilə venadaxili maye infuziyaları və elektrolitlərin korreksiyasına start verilmişdir.

Xəstənin vəziyyətinin ağırlığını, əməliyyat riskinin yüksək olmasını, patologiyanın xarakteri və xəstənin yaşını nəzərə alaraq, az invaziv prosedurların (dekompressiv kolonoskopiya, yoğun bağırsağın stenozlaşmış hissəsinə özüaçılan metal stentin (SEMS, self-expanding methallic stent) qoyulması) aparılması müzakirə edilmişdir. Lakin həmin prosedurların müxtəlif səbəblərdən (SEMS əlçatan olmaması; bağırsaq möhtəviyyatı səbəbindən kolonoskopiyanın uğursuz olması) təcili qaydada icrası mümkün olmamışdır.

Yoğun bağırsağın tam mexaniki obstruksiyası mövcud olduğundan və yuxarıda qeyd edilmiş konservativ metodlar nəticə vermədiyi səbəbindən, xəstə hazırlanaraq təcili qaydada cərrahi əməliyyata götürülmüşdür. Oməliyyat zamanı (əməliyyat müddətini qısaltmaq məqsədilə pararektal kəsik aparılmışdır) kor və qalxan çənbər bağırsaqların kəskin genişlənməsi (13-15 sm), yoğun bağırsağın hepatik fleksura nahiyyəsində bağırsaq mənfəzini tam obstruksiya edən, sərt, çələ-çötür bərk törəmənin olması (çox guman ki, adenokarsinomanın yerli residivi) müəyyən edilmiş və kor bağırsaq ekstraperitonizasiya olunduqdan sonra kor bağırsaq divarında enterotomiya aparılmış, obstruksiyaya proksimal yoğun və nazik bağırsaq mənfəzi dekompressiya olunaraq sekostomiya çıxarılmışdır.

Xəstənin ağır klinik vəziyyətini, yanaşı xəstəliklərini, habelə əməliyyatın təcili olduğunu nəzərə alaraq, az travmatik və icrası az vaxt tələb edən bir paliativ dekompressiv əməliyyatın seçilməsi və icra olunması nəticəsində xəstənin vəziyyəti tam yaxşılaşmış və əməliyyatdan sonrakı 7-ci gün xəstə evə yazılmışdır.

Açar sözlər: yoğun bağırsaq xərçəngi, mexaniki obstruksiya, bağırsaq keçməzliyi, kolostoma, meqakolon

Maliyyə mənbəyi: Tədqiqatın aparılması üçün digər qurumlardan və ya şəxslərdən əlavə maliyyə vəsaiti cəlb edilməmişdir. Maraqların toqquşması: YOXDUR. 


\section{XəSTOLIK TARIXi.}

Təxminən 5-6 gündür ki, 85 yaşlı kişi xəstə bağırsaqlarının boşaldılmamasından, arabir ürək bulanması və qarın ağrısından şikayətlənir. Evə təcili tibbi yardım həkiminin çağırılmasının səbəbi isə əsasən qarında ağrı və xəstənin qohumlarının bu ağrının kəskin qarın olmasında narahatçılığı olub. Xəstədə əvvəllər qəbzlik olsa da, o adətən iki gündən bir bağırsaqlarını boşalda bilib və son bir neçə günədək ürək bulanmadan və qarın ağrısından şikayətlənməyib. Xəstə qusmanın olmadığını, sidiyə normal getdiyini qeyd edib. $O$ həmçinin hər hansı digər simptomların olmadığını söyləyib. Xəstə həmçinin son nəcisin rənginin qəhvəyi olduğunu qeyd edib. Lakin qohumların dediyinə görə bir müddət əvvəl onun nəcisinin rəngi qara olub.

Xəstənin bədən çəkisi dəqiq bilinməsə də, özünün və qohumlarının dediyinə görə xəstənin çəkisi sabit qalıb. Bununla yanaşı 3-4 həftə öncə xəstədə beyin qan dövranının tranzitor tipli pozulması baş verib və nevropatoloqun müayinəsindən sonra xəstəyə venadaxili infuziyalar, habelə beyin qan dövranını yaxşılaşdıran preparatlar təyin edilib. Ümumiyyətlə, qohumların dediyinə görə xəstə son illərdə artıq bir neçə dəfə beyin qan dövranın tranzitor pozulması ilə üzləşib. Bir neçə il əvvəl isə xəstə ilk dəfə insult keçirmiş və ondan sonra sağ tərəfli hemiplegiya nevroloji fəsad kimi qalmaqdadır. Buna baxmayaraq, xəstənin nitqi normaldır, son illərdə əlavə nevroloji defisiti qeydə alınmayıb və xəstə teztez oturacaq-kresloda otuzdurulur və əlil arabasında oturaraq gəzdirilir. Lakin ilk insultdan sonra xəstənin yeriməsi xeyli çətinləşib və o köməksiz bir neçə ildir $\mathrm{ki}$, sərbəst yeriyə bilmir.

Xəstə requlyar olaraq qan təzyiqi dərmanı, şəkərli diabetə görə insulin və metformin qəbul edir. Xəstə heç bir antikoaqulyasiya və antitrombositar terapiya almır. Lakin, qohumların dediyinə görə arada ona aspirin $81 \mathrm{mq}$ dozada verilib. Aspirinin son dozası bir ay əvvəl olub.

\section{Anamnesis vitae.}

Təxminən 11 il əvvəl xəstədə yoğun bağırsaq keçməzliyi inkişaf etmiş və Bakıda yoğun bağırsaq xərçənginə görə kolostomanın çıxarılması ilə köndələn bağırsağın hissəvi rezeksiyası əməliyyatını keçirmişdir. Aparılmış əməliyyat zamanı rezeksiya olunmuş yoğun bağırsaq seqmentinin histopatoloji müayinəsində aşağı differensiasiyalı adenokarsinoma aşkar edilmişdir. $\mathrm{Bu}$ əməliyyatdan 6-8 ay sonra Moskva şəhərində kolostoma bağlanaraq yoğun bağırsağın tamlığı bərpa olunmuşdur. Nəticədə xəstədə böyük ventral yırtıq əmələ gəlmişdir. Xəstənin klinik vəziyyəti və yaşını, habelə yanaşı xəstəliklərini nəzərə alaraq, kimya terapiyası və ya şüa terapiyasının aparılması tövsiyə edilməmişdir.
Xəstədə həmçinin yuxarıda qeyd edilmiş əməliyyatlardan 4 il sonra sidiyə getmənin pozulması inkişaf etmiş və Türkiyədə aparılmış TUR əməliyyatı nəticəsində sidiyə getmə bərpa olunmuşdur.

Bununla yanaşı xəstə 15 il əvvəl ilk işemik beyin insultu keçirmişdir. Həmin insultdan sonra xəstədə sağ tərəfli hemiplegiya inkişaf etmişdir. Son bir neçə il ərzində xəstədə 1-3 dəqiqə davam edən beyin qan dövranın keçib gedən (tranzitor) pozğunluğu müşahidə edilib. Lakin, həmin hadisələrin daha ətrafı araşdırıması, o cümlədən, beyinin MRT görüntüləməsi, nevroloji müayinə nəticəsində yeni beyin-damar xəstəliyi və ya kəskin insult ocaqları aşkar edilməmişdir. Sonuncu dəfə xəstədə tranzitor beyin işemiyası 1 ay əvvəl baş vermiş və nevropatoloqun müayinəsindən sonra dəstəkləyici infuzion terapiya təyin edilmişdir. 6-7 ay öncə xəstə yenidən beyinin işemik insultu keçirmiş və KT-də sağ oksipital payın işemiyası təsdiqlənmişdir. Bu işemik insult nəticəsində xəstədə görmə pozğunluğu baş vermişdir.

Xəstədə bir sıra epileptik qıcolmalar da baş verib. Lakin sonuncu epileptik qıcolma bir il əvvəl olub. Epileptik status olmayıb.

Xəstə artıq 10 ilə yaxındır ki, şəkərli diabetdən əziyyət çəkir və son illərdə şəkərin kontrol olunması üçün metformin və insulindən istifadə edir.

Xəstədə son bir neçə ildə qəbzlik halları baş versə də, onlar qısa müddətli olmuş və bağırsaq işlədicilərin köməyi ilə tez bir zamanda ötüşmüşdür.

Son bir neçə il ərzində sidik yolları infeksiyası halları baş vermiş, habelə əvvəlki hospitalizasiya zamanı xayalığın ödemi də müşahidə edilmişdir.

DORMANLAR. Xəstənin hazırda qəbul etdiyi dərmanlar: ramipril $5 \mathrm{mq}$, rosuvostatin $20 \mathrm{mq}$, aspirin $81 \mathrm{mq}$ (bir aydır ki dayandırıb).

\section{SISTEMLORIN ICMALI.}

- Nevroloji/Psixi: yüngül depressiya halları olur, lakin ümumən əhvalı pis olmur; yeni nevroloji defisit qeydə alınmayıb; nitqi pozulmayıb; lakin udma prosesində çətinliklər tez-tez olur. Belə ki, xüsusilə də, suyun qəbulu zamanı xəstədə çeçəmə müşahidə edilir.

- Ürək-damar sitemi: sinədə və ya ürək nayihəsində heç bir ağrı, boğulma hissi və ya ağırığın olmasını inkar edir; lakin bəzən ürək döyüntülərinin olmasından şikayət edir.

- Tənəffüs sistemi: təngənəfəslik və ya nəfəsalmada çətinlik yoxdur; öskürək olmur;

- Mədə-bağırsaq sistemi: mədə nayihəsində ağrı yoxdur; ürək bulanma artıq 5-6 gündür ki var, lakin qusma olmayıb. Bağırsaqları da 5-6 gündür $\mathrm{ki}$, boşalda bilmir; nəcis sonuncu dəfə qəhvəyi 
olub, lakin bir müddət əvvəl bir dəfə qara-qəhvəyi rəngli olub; nəcisdə qırmızı qan olmayıb.

- Sümük-əzələ sistemi: ümumi zəiflik var; sağ aşağı ətrafda tez-tez küt inildiyən ağrılar olur;

\section{FiZiKi MÜAYiNO.}

- Həyati göstəricilər: AT 120/75 mm c.s., nəbzi 100-110/dəqiqədə, hərarəti 36.8C, SaO2=95\% otaq havasında.

- Ümumi: 84 yaşlı zəifləmiş, yaşına uyğun görünən və yüngül distresdə olan kişi xəstə.

- Baş-boyun-göz-qulaq: boğaz təmizdir, eritema yoxdur, dil qurudur, uvula orta xətt üzrədir; skleralar ikterik deyil; eşitmə bir qədər zəifdir. Bəbəklərin diametri $3 \mathrm{~mm}$, yumru və eynidir, bəbəklərin işığa reaksiyası normaldır.

- Ürək-damar sistemi: S1, S2 ürək tonları eşidilir, ritm və ürəyin vurma tezliyi requlyardır, küy və at çapması tonu eşidilmir.

- Tənəffüs sistemi: ağciyərin bütün hissələrinə tənəffüs keçirilir, lakin hər iki aşağı paylara hava keçiriciliyi bir qədər zəifdir; xırıtılar qeydə alınmır.

- Mədə-bağırsaq sistemi: qarın asimmetrikdir, köpdür, böyümüşdür və ağrııdır; peritonun qıcıqlanma əlamətləri qeydə alınmır; orta xətt üzrə böyük ventral yırtıq (30 sm x 30 sm ölçüdə) müəyyən olunur; bağırsaq küyləri eşidilmir; palpasiyada diffuz qarın ağrısı müəyyən edilsə də, əsas ağrı qarının sağ yarısında müəyyən edilir. Rektal müayinədə rektum boşdur, anal sfinkterin tonusu norma daxilindədir; xarici və daxili hemorroidal düyünlər əllənmədi.

- Sidik-cinsiyyət sistemi: meatusda qan və ya irinli ifrazat yoxdur; scrotum (xayalıq) ödemli və ağrıı deyil;

- Nevrologiya: sağ tərəfli hemiplegiya; sağ tərəfdə hissiyat $0 / 5$ və əzələ gücü $0 / 5$ kimi qiymətləndirilir. Nitqi qüsursuzdur; aşağı ətrafların hər ikisində və sağ yuxarı ətrafda əzələlərin hipotoniyası və ağır dərəcəli hipotrofiyası mövcuddur. Dərin vətər refleksləri sağda $1 / 5$ kimi qiymətləndirilir.

- Dəri: solğundur, sarılıq əlamətləri yoxdur; qarın divarında kolostoma və orta laparotomiya kəsiyindən çapıqlar qeydə alınır. Dəri turqoru aşağıdır.

\section{LABORATOR ANALIZLOR.}

\section{Hospitalizasiya olunduğu gün:}

QÜA: Leykositlər 10.62*10*9/L; Eritrositlər

5.79*10*12/L; Hb 105 g/L; Hct 36.5\%; Trombositlər 381*10*9/L; EÇS $15 \mathrm{~mm} /$ saatda; Neytrofillər $72.2 \%$.

Biokimyəvi analizlər: Kreatinin $63 \mathrm{mkmol} / \mathrm{l} ; \mathrm{CRP}$ $19.7 \mathrm{mg} / \mathrm{dL}$,

Elektrolitler: Kalium $-5.3 \mathrm{mmol} / \mathrm{L}$, Kalsium - 2.4 $\mathrm{mmol} / \mathrm{L}$, Natrium - $150 \mathrm{mmol} / \mathrm{L}$, Maqnezium - 2.14 $\mathrm{mg} / \mathrm{dL}$.
SÜA: bulanlıq, pH neytral (7.0), zülal 0, ketonlar 0, bilirubin 0 , nitritlər 0 .

Sidik çöküntüsünün analizi: yastı epiteliy 4-5 görmə sahəsində, leykositlər 2-3 görmə sahəsində, eritrositlər 0-1 görmə sahəsində, bakteriyalar -0 , selik -0, silindrlər -0 .

Qaraciyər paneli: ALAT 6.43 U/L, AST 10.2 U/L, Pancreatik amilaza $16.2 \mathrm{U} / \mathrm{L}$, ümumi bilirubin 7.0 $\mathrm{mkmol} / \mathrm{L}$

Koaquloqram: INR 1.0; aPTT 29.7 saniyə,

Arteriyal qan qazları: pH 7.42, pCO2 26.8, pO2 87, HCO3 17.4, BE ecf -7, sO2 97\%, Laktat 1.78 $\mathrm{mmol} / \mathrm{L}$.

\section{2 saat sonra (əməliyyat qabağı):}

QÜA: Leykositlər 13.53*10*9/L; Eritrositlər 5.25*10*12/L; Hb 97 q/L; Hct 33.7\%; Trombositler $349 * 10 * 9 / \mathrm{L}$; EÇS $10 \mathrm{~mm} /$ saatda; Neytrofiller $88 \%$. Biokimyəvi analizlər: Kreatinin $74.6 \mathrm{mkmol} / /$; CRP $58.3 \mathrm{mg} / \mathrm{dL}$, Laktat $5.0 \mathrm{mmol} / \mathrm{L}$; Ümumi zülal $4.2 \mathrm{q} / \mathrm{L}$, albumin - $2.4 \mathrm{q} / \mathrm{L}$.

Elektrolitlər: Kalium $-5.4 \mathrm{mmol} / \mathrm{L}$, Kalsium - 2.4 $\mathrm{mmol} / \mathrm{L}$, Natrium - $146 \mathrm{mmol} / \mathrm{L}$, Maqnezium - 1.85 $\mathrm{mg} / \mathrm{dL}$.

\section{DIAQNOSTIK MÜAYINOLOR.}

Ağciyərlərin bəsit rentgen müayinəsində aşağıdakılar müşahidə edilir:

- ocaqlı və ya diffuz infiltratlar aşkar edilmir, sinuslar açıqdır, diafraqmanın hər iki qövsü normal səviyyədədir, ürəyin kölgəsi bir qədər sola böyümüşdür.

Kolonoskopiya:

- Xəstənin daxil olduğu gün aparılmış kolonoskopiya bağırsaq mənfəzində çoxlu miqdarda nəcisin olduğu səbəbdən uğursuz olmuşdur. Dekompressiyaya cəhdlər nəticə verməmişdir.

- Özüaçılan metal stentlər (SEMS) əlçatan olmadığından obturasiya bölgəsinin stentlənməsi aparılmamışdır.

Qarın boşluğunun venadaxili (VD) və per oral kontrastla KT görüntüləməsi:

- Qarın boşluğu sağ-ön divarında qeniş ventral yırtıq sahəsi izlənilir. Yoğun bağırsaqda hepatic curvatura proyeksiyasında $60 \mathrm{~mm}$ uzunluqda olan seqmentdə divarın sirkular qalınlaşması (40 $\mathrm{mm}-ə$ qədər) və mənfəzin daralması izlənilir. Buna bağlı olaraq bu səviyyədən proksimal yerləşən bağırsaq ilgəklərində dilatasiya (96 mmə qədər), divaryanı hava və "hava-maye" səviyyələri qeyd edilir (bağırsaq keçməməzlik əlamətləri). Sağ parakolik nahiyədə cüzi maye yığıntısı, piy toxumasının sıxlığ dərəcəsinin artması və ən böyüyü $21 \times 20 \mathrm{~mm}$ ölçüdə olan bir neçə ədəd patolojı limfa düyünləri izlənilir. 


\section{EXO-KQ:}

- Aortanın divarları sklerozlaşıb. Sol qulaqcığın boşluğu az dərəcədə böyüyüb. Ürəyin digər boşluqları norma daxilindədir. Mitral və aortal klapanların fibrozlaşması, köklərində isə kalsinatlar qeydə alınır. Klapan qapaqlarının açılması normaldır. Sol mədəciyin divarı konsentrik olaraq hipertrofiyalıdır. Miokardın lokal yığılması və sol mədəciyin ümumi nasos funksiyası norma daxilindədir. Doppleroqrafiya zamanı sol mədəciyin diastolik funksiyasının pozğunluğu (relaksativ növ); aortal klapanda 1-ci dərəcəli requrgitasiya; mitral klapanda zəif requrgitasiya izlənilir.

\section{$E K Q:$}

- Cərrahi müdaxilədən öncə: sinus ritmi, ekstrasistolalar qeyd edilir.

- Cərrahi müdaxilədən sonra: qulaqcıqların fibrilyasiyası; monomorph mədəcik ekstrasistolaları. Otraf ötürmələrdə QRS komplekslərinin aşağı amplitudası qeyd edilir. Ürəyin elektrik oxu horizontaldır. Sol mədəciyin hipertrofiyası və xroniki koronar çatışmazlıq səbəbindən miokardın metabolik dəyişiklikləri qeyd edilir.

\section{HOSPITALIZASIYA DÖVRÜ.}

84 yaşlı bu kişi xəstə hospitalizasiya üçün evdən xəstəxanaya gətirilmiş və böyrək funksiyasının qiymətləndirilməsi üçün qan və sidik analizlərinin nəticələrini gözləyərklən, təcili qarın və çanaq boşluğunun kontrastsız KT görüntüləməsi aparımışdır. Kontrastsız KT görüntüləməsində yoğun bağırsaq keçməzliyinə dəlalət edən yoğun bağırsaq ilgəklərinin hepatik fleksuraya proksimal hissələrdə dilatasiyası və hava-maye səviyyələri müəyyən edilmişdir. KT-də yoğun bağırsağın diametrinin 9-10 sm-dək böyüdüyü qeydə alınmışdır.

KT görüntüləməsindən dərhal sonra xəstənin klinik vəziyyəti və hemodinamikasının stabilliyini nəzərə alaraq, habelə cərrahi müdaxilə riskinin yüksək olduğunu diqqətdə saxlayaraq, konservativ müalicəyə üstünlük verilmişdir. $\mathrm{Bu}$ məqsədlə kolonoskopiya təyin edilmişdir. Paralel olaraq qida və maye qəbulunun dərhal dayandırılması, mədə daxilinə nazoqastral zondun yerləşdirilməsi (xəstə NPO və yanil per os edilmişdir) təmin olunmuşdur. Elektrolitlərin korreksiyası, habelə mərkəzi venoz təzyiqin monitorinqi altında mərkəzi venoz kateter vasitəsilə Rinqer məhlulu və $0.9 \%-l ı \mathrm{NaCl}$ məhlulu ilə maye infuziyasına, venadaxili metoklopramid, habelə bisakodil PO və rektal şamlar ilə bağırsaq aktivliyinin stimullaşdırılmasına start verilmişdir. Növbəti saat ərzində effekt olmadığından, kiçik həcmli qliserinli imalələr edilmişdir. Bununla yanaşı yüngül sedasiya ilə dekompressiv kolonoskopiyaya iki dəfə cəhd edilmiş, lakin kolonoskop yalnız splenik fleksurayadək irəliləyə bilmişdir.

Qan və sidik analizlərinin nəticələri əldə edildikdən sonra qarın və çanağın $P O$ (per os) və VD (venadaxili) kontrastla $\mathrm{KT}$ görüntüləməsi təkrar aparılmış və müsbət dinamikanın olmadığı ilə yanaşı, hepatik fleksurada köndələn bağırsaq mənfəzini sıxan dairəvi qalınlaşma (törəmə) müəyyən edilmişdir.

Hospitalizasiyanın ilk 12 saatı ərzində xəstənin hemodinamikası stabil olaraq qalmış, lakin konservativ müalicənin effekitv olmadığından xəstənin uzun illər yataq xəstəsi olduğu, hipotrofiyanın ağır dərəcəsindən əziyyət çəkdiyini nəzərə alaraq, əməliyyat risklərini və xəstənin sağ qalması şansını artırmaq üçün xəstənin cərrahi müdaxiləyə aktiv hazırlanmasına start verilmişdir. Bu məqsədlə maye infuziyası, albumin infuziyası və parenteral qidalanma davam etdirilmişdir.

Perioperativ antibiotiklər verildikdən sonra xəstə dekompressiv cərrahi müdaxiləyə götürülmüşdür. Xəstənin əməliyyata hazırlığı tamamlandıqda sonra böyük ventral yırtığın olması və bağırsaq ilgəklərinin medial laparotomiya xəttinə çox bitişik yerləşdiyini nəzərə alaraq, əməliyyat üçün paramedian laparotomiya aparılmışdır. Qarın boşluğuna daxil olduqda çoxlu miqdarda bitişmələr aşkar edilmiş, onlar küt və iti disseksiya ilə açılmış, bu proses zamanı heç bir enterotomiyaya yol verilməmişdir. Qarın boşluğunun təftişi nəticəsində kor bağırsaq (lat. cecum), qalxan bağırsaq (lat.colon ascendens) və köndələn bağırsağın (lat. colon transversus) diametrinin normadan artıq olduğu (xüsusilə də, kor bağırsaq səviyyəsində 13-15 smdək çatdığı) aşkar edilmiş, hepatik fleksurada isə köndələn bağırsaq mənfəzini təxminən 4-5 sm-dək uzunluqda sıxan, bərk sərt hərəkətsiz və ətraf toxumulara invaziya etmiş kələ-çötürlü törəmə palpasiya olunmuşdur.

Xəstənin kliniki vəziyyətinin ağırlaşma riskini yüksək olduğunu, bağırsaq obstruksiyasının olmasını, habelə ağır dərəcəli malnutrisiya vəziyyətini nəzərə alaraq, kor bağırsaq divarında enterotomiya aparılmış, bağırsaq mənfəzində çoxlu miqdarda qaz və möhtəviyyat boşaldılmış, yoğun və nazik bağırsaq dekompressiya olunmuş və yuyulmuşdur. Daha sonra isə Bruk metodu ilə sekostomiya çıxarılmış, qarın boşluğuna iki drenaj qoyularaq əməliyyat tamamlanmışdır. Pararektal (paramedian) cərrahi kəsik düyünlü fasiləli tikişlərlə tikilərək bağlanmışdır. Oməliyyat ümumən 2 saat ərzində tamamlanmış və xəstə postoperativ dövrdə reanimasiya köçürülmüşdür.

Oməliyyatdan dərhal sonrakı dövr ağırlaşmasız keçmiş, xəstə əməliyyatdan 8 saat sonra ekstubasiya olunmuşdur. Xəstənin nevroloji və 
kardioloji müayinəsi heç bir yeni pozuntuların olmadığını təsdiq etmişdir. Sekostoma üçüncü postoperativ gün aktiv işləməyə başlamışdır. Xəstənin klinik vəziyyəti tam normallaşmış, qan analizlərinin nəticələrinə əsasən qidalanma statusunda pozitiv dinamika baş vermişdir. Postoperativ dövrdə xəstənin parenteral qidalanması davam etdirilmiş, sekostomanın fəaliyyəti başladıqda isə dördüncü postoperativ gün təmiz maye ilə enteral qidalanmasına start verilmiş və yeddinci postoperativ gün disfagiyaya uyğun pəhriz, habelə stoması olan xəstələrin qidalanması qaydalarına uyğun tövsiyələrlə xəstə evə yazıımışdır. Evə yazılan gün götürülmüş analizlərdə Kreatinin $65.4 \mathrm{mkmol} / \mathrm{L}$, INR 1.35, Kalium 3.64 $\mathrm{mmol} / \mathrm{L}$, Natrium $146.4 \mathrm{mmol} / \mathrm{L}$, Leykositlər $9.38^{*} 10^{*} 9 / \mathrm{L}, \mathrm{Hb} 92 \mathrm{qm} / \mathrm{L}$, Hct $30.3 \%$, Trombositler $323^{*} 10 * 9 / \mathrm{L}$, EÇS - $25 \mathrm{~mm} / \mathrm{saatda}$ olmuşdur. Xəstənin qidalanma statusunun yaxşılaşdırılması və ümumi vəziyyətinin bərpasının sürətləndirilməsi üçün aminturşular, lipidlər və vitaminlərlə zəngin məhlulla parenteral qidalanması 5 gün də davam etdirilmiş və evə yazıldıqda dayandırılmışdır.

Xəstənin evə yazılmasından iki həftə sonra paramedian kəsiyə qoyulmuş tikişlər fəsadsız sökülmüş, stomanın normal fəaliyyəti bir daha təsdiq edilmişdir. İki həftə sonra götürülmüş laborator analizlərdə ümumi protein $(5.7 \mathrm{q} / \mathrm{L})$ və albuminin (2.9 q/L) səviyyəsinin yaxşılaşmış, kreatininin və elektrolitlərin səviyyələrinin norma daxilində olmuşdur. Oməliyyatdan beş həftə sonra götürülmüş analizlərdə bir daha müsbət dinamika qeyd edilmişdir. Xəstənin bir ay sonra müayinəsində sekostomanın yaxşı işləməsi, sekostoma ətrafı dərinin təmiz və sağlam olması, drenaj yerlərinin tam sağalması, habelə $1 \mathrm{sm}$ ölçüdə olan aşağı hissəsi istisna olmaqla paramedian kəsik yeri tam sağalmışdır.

\section{MÜZAKIRO.}

Yoğun bağırsağın bədxassəli və xoşxassəli obstruksiyasında endoskopiya mühüm rol oynaya bilər. Obstruksiyanın səbəbinin öyrənilməsi, diaqnostika üçün toxuma biopsiyasının əldə edilməsi və hətta müalicənin aparılması üçün kolonoskopiyanın təyin edilməsi tələb oluna bilər. Kolorektal kanseri olan xəstələrin təxminən 15-20\%də yoğun bağırsağın obstruksiyası baş verir. Metastazlaşmış kanser və çanağın lokal irəliləmiş törəmələri də yoğun bağırsağın obstruksiyasına səbəb ola bilər.

Yoğun bağırsağın obstruksiyası həm də xoşxassəli (yəni maliqnant proseslə əlaqəli olmayan) səbəblərdən əmələ gələ bilər. Bunlara volvulus (bağırsağın burulması), Kron xəstəliyi, divertikulit, anastomoz yerində daralma (striktura), şüa terapiyasından sonra yaranmış zədələnmə, işemiya, yad cismlərin tıxanması və invaginasiya aid edilir.
Yuxarıdakı xəstəlik tarixçəsinin icmalı pasiyentdə daha çox bədxassəli (yoğun bağırsaq xərçənginin lokal residivi) proses səbəbindən mexaniki obstruksiyanın olmasından xəbər verir.

\section{Yoğun bağırsaq obstruksiyası hallarında ilkin müayinə.}

Yoğun bağırsaq obstruksiyası adətən yüngül diskomfort və ya bəzən ağır dərəcəli periumbilikal və ya hipoqastrik ağrı və qarın köpməsi ilə müşaiyət olunur. Ağır və davamlı ağrı və ya peritonun qıcıqlanması əlamətləri olan xəstələrdə yoğun bağırsağın tam obstruksiyası və ya bağırsağın qanqrenasının olduğu dərhal düşünülməlidir. Həmin xəstələrin cərrahi müayinəyə yönəldilməsi tələb olunur. Bu qrup xəstələrdə kolonoskopiyanın aparılması əksgöstərişdir. Belə ki, onsuz da dilatasiya olunmuş bağırsaq daxilinə havanın insuflyasiyası bağırsaq divarının perforasiyasına səbəb ola bilər. Yoğun bağırsaq obstruksiyası hallarında əldə edilmiş abdominal rentgen filmlərində bağırsaqda obstruksiya sahəsinə proksimal hissələrdə yoğun bağırsağın dilatasiyası, habelə ayaqüstə və ya dekubitus filmlərdə havamaye səviyyələri müəyyən edilir. Volvulus çox vaxt qarın boşluğunun bəsit rentgenoqrafiyası ilə müəyyən edilə bilər. Abdominal KT görüntüləməsi də obstruksiyasının yerini və onun mümkün etiologiyasını təyin etməyə yardımçı ola bilər.

Bağırsağın hissəvi keçməzliyi diaqnozu təsdiqini tapdıqda, xəstənin müalicəsi üçün venadaxili maye infuziyası və elektrolitlərin korreksiyasına start verilir, habelə bağırsağın dekompressiyası üçün nazoqastral zondun mədəyə yerləşdirilməsi ilə möhtəviyyatın xaric edilməsi təmin edilir. Bundan sonra obstruksiyasının sahəsinin müayinəsi aparıla bilər. Bu məqsədlə radioloji görüntüləmə və ya kolonoskopiya ilə vizualizasiya istifadə edilə bilər. Yoğun bağırsağın sol tərəfli obstruksiyası hallarında qatlanan siqmoidoskopiya və ya məhdud kolonoskopiya obstruksiyanın yerini müəyyən etməyə və anal dekompressiya borularının, özüaçılan metal stentlərin qoyulması və ya endoskopik dekompressiya ilə müalicəsinin aparılmasına imkan verə bilər. Qatlanan siqmoidoskopiya və ya məhdud kolonoskopiyanın əlverişliyi onun aparılması üçün bağırsağın yalnız təmizləyici imalə ilə hazırlanmasının tələb olunduğundan irəli gəlir.

Yoğun bağırsağın sağ tərəfli patologiyalarında endoskopik müayinə bir daha faydalı ola bilər, lakin onun aparıması texniki cəhətdən daha çətindir. Bununla yanaşı sağ tərəfli yoğun bağırsaq patologiyalarının müayinəsi üçün bağırsağın daha yaxşı hazırlanması tələb olunur ki, bu da bağırsağın perforasiyası riskini artırmış olur. Bağırsaq obstruksiyası olan xəstələrdə kontrast maddə ilə imalənin aparılması planlaşdırılarsa, barium kontrast 
əvəzində suda həll olunan (məs., qastroqrafin, uroqrafin) kontrastın istifadəsinə üstünlük verilməlidir. Belə ki, bariumun istifadəsi nəticəsində bağırsağın obstruksiyası zonasında bariumun tıxanması və ya gizli qalmış perforasiya hallarında bariumun qarın boşluğuna sızaraq barium peritonit riski artmış olur. Barium kontrast maddəsi ilə aparılmış görüntüləmə bağırsağın selikli gişasının daha detallı müayinəsinə imkan versə də, mexaniki obstruksiya ehtimalı olan xəstələrdə bu cür detallı müayinəyə ehtiyac duyulmur.

\section{Bədxassəli yoğun bağırsaq obstruksiyası.}

Yoğun bağırsaq obstruksiyası hallarının 70\%-i yoğun bağırsağın adenokarsinoması səbəbindən baş verir. Yoğun bağırsaq adenokarsinoması bir çox hallarda yoğun bağırsağın sol tərəfli obstruksiyasına səbəb olur və əksər hallarda obstruksiya siqmavari bağırsaqda lokalizasiya olur. Digər bədxassəli törəmələrin yoğun bağırsağa metastazları da yoğun bağırsağın obstruksiyasına səbəb ola bilər. Çanaqdaxili törəmələr də yoğun bağırsağın ekstrinsik kompressiyası vasitəsilə və ya yoğun bağırsağa invaziya nəticəsində yoğun bağırsağın obstruksiyasına səbəb ola bilər. Yoğun bağırsağın bədxassəli obstruksiyası hallarında aşağıdakı müalicəvi tədbirlər görülə bilər:

- birincili anastomozla tamamlanan cərrahi rezeksiya və ya

- obstruksiya sahəsinə dəymədən yönləndirici stomanın çıxarılması.

- Lakin maliqnant proses səbəbindən bağırsaq obstruksiyası olan xəstələrin bir qisminin cərrahi riski çox yüksək olduğundan, onlarda cərrahi müdaxilənin aparılması mümkün olmur. Həmin hallarda təcili cərrahi müdaxilə yüksək mortalite $(>10 \%)$ və xəstələnmə $(>40 \%)$ ilə əlaqəlidir.

Yönəldici kolostomanın çıxarılması əməliyyatı keçirmiş xəstələrin bir qismində metastazlar aşkar edildiyi üçün stoma uzun müddət saxlanılır. Maliqnant (bədxassəli) yoğun bağırsaq obstruksiyası hallarında təcili cərrahi müdaxiləyə alternativ kimi törəmənin ablasiyası və dekompressiyaedici boruların qoyulması və ya özüaçılan metal stentlərin yerləşdirilməsi tətbiq oluna bilər. Ümumiyyətlə, bədxassəli törəmə səbəbindən yaranmış yoğun bağırsaq obstruksiyası olan xəstələrin müalicəsində cərrahlarla yanaşı endoskopistlər, tibbi onkoloqlar, terapevtlər, qidalanma üzrə ekspertlər və s. mütəxəssislərin komanda şəklində iştirakı xüsusi əhəmiyyət kəsb edir.

\section{Törəmə kütləsinin kiçildiməsi və ya hissəvi rezeksiyası.}

Endoskopik lazer terapiyası, arqon plazma koaqulyasiyası və arqon plazma koaqulyasiyası ilə və ya onsuz aparılan polipektomiya kolorektal xərçəngi olan və cərrahi rezeksiyanın aparılması mümkün olmayan və ya istməyən xəstələrdə törəmə kütləsinin həcminin azaldılması məqsədilə geniş istifadə edilir. Oksər tədqiqatlarda həmin metodların tətbiqi obstruksiya ilə bağlı simptomların 65-85\% hallarda aradan qalxmasına imkan verib. Әn çox araşdırılmış və effektivliyi sübuta yetirilmiş metod endoskopik lazer terapiyasıdır. Lakin bir çox hallarda obstruksiyanın aradan qaldırılması məqsədilə törəmənin kütlə həcminin kiçildilməsi üçün 4-7 seans lazer terapiyası tələb olunur. Arqon plazma koaqulasiyası ilə törəmənin ablasiyası da bir sıra hallarda uğurla aparılıb, lakin bu metodun effektivliyi yalnız kiçik həcmli tədqiqatlarda göstərilib.

\section{Yoğun bağırsaq daxilinə transanal yolla dekompressiyaedici boruların yerləşdirilməsi.}

Yoğun bağırsağın transanal dekompressiyası yönəldici kolostomaya bir alternativdir. Bədxassəli yoğun bağırsaq obstruksiyası hallarında yoğun bağırsaq daxilinə endoskopik yolla transanal dekompressiv boruların yerləşdirilməsi bir sıra iri tədqiqatlarda araşdırılmışdır. Düzdür, transanal yolla yerləşdirilən boruların diametri kiçik olduğundan bağırsağın effektiv təmizlənməsi mümkün olmasa da, həmin borular vasitəsilə yoğun bağırsaq daxilində toplanmış qazın dekompressiyası klinik yaxşılaşmaya xeyli təsir göstərmiş olur. Transanal dekompressiv borular yerləşdirildikdən sonra əksər xəstələrdə kolostoma çıxarılmadan bir etaplı cərrahi müdaxilənin aparılması mümkün olur. Lakin buna baxmayaraq transanal boruların tətbiqi az yayılmışdır. Bununla yanaşı, boruların əlverişsizliyi onların bəzən bağırsaqdan qovulması və ya mənfəzinin tutulması, onlara qayğınınt təmin edilməsi üçün müvafiq resursların tələb olunması və həmçinin boruların uzun müddətli istifadəsinin mümkünsüzlüyü və xəstənin diskomfortu ilə bağlıdır.

\section{Maliqnant obstruksiya hallarında özüaçılan metal stentlerin qoyulması.}

Yoğun bağırsaq obstruksiyası hallarında bağırsağın cərrahi dekompressiyasına alternativ kimi kolorektal stentlərin endoskopik yolla qoyulması tətbiq olunur. Aparılmış 50-dən çox klinik tədqiqatların nəticəsində məlumdur ki, özüaçılan metal stentlərin qoyulması $90 \%$-dan çox hallara yoğun bağırsaq obstruksiyasını aradan qaldırmağa müvəffəq olur. Özüaçılan metal stentlərin (SEMS, self-expanding methallic stents) qoyulması zamanı ciddi ağırlaşmalar $<5 \%$-dan az hallarda müşahidə edilir. Sağ tərəfli yoğun bağırsaq obstruksiyası hallarında SEMS-tipli metal stentlərin qoyulması çox yaxşı 
nəticələr verir. Lakin sol tərəfli yoğun bağırsaq obstruksiyası hallarında metal stentlerin yerləşdirilməsinə dair praktik təcrübə daha azdır. Ümumiyyətlə, stentlərin yerləşdirilməsi ilə bağlı aparılmış çoxsaylı tədqiqatlardan aşağıdakı məqamları diqqəti çəkmək lazımdır:

- Stentlərin qoyulmasında öncə bağırsaq mənfəzinin daralmasının (strikturasının) dilatasiyası bağırsağın perforasiyası riskini 5-6 dəfə artırır və buna görə tətbiq edilməməlidir.

- Örtüklü stentlərlə müqayisədə örtüksüz stentlərin qoyulması daha yaxşı klinik nəticələr verir. Buna səbəb isə örtüklü stentlərin daha çox hallara miqrasiya etməsidir.

- Kolostomanın çıxarılması ilə müqayisə etdikdə isə yoğun bağırsaq daxilinə metal stentlərin qoyulması daha sərfəlidir və ağırlaşma riski məqbuldur.

\section{Cərrahi müdaxiləyə keçid üçün Yoğun bağırsağa özüaçılan metal stentlərin qoyulması.}

Maliqnant kolon obstruksiyası olan və cərrahi rezeksiyanın aparılması planlaşdırılan xəstələrdə özüaçılan metal stentin qoyulması yoğun bağırsağın dekompressiyasına və təcili cərrahi müdaxiləni müşaiyət edən mortalite və xəstələnməyə yol verməməyə imkan verir. SEMS-in qoyulması daha az hallarda ağırlaşmalara səbəb olur, hospitalizasiya müddətini azaldır, daha çox hallarda birincili anastomozun qoyulmasına imkan verir və təcili cərrahi müdaxilə ilə müqayisədə daha az halalrda kolostomiyanın qoyulması ilə nəticələnir.

SEMS-tipli kolorektal stentlərin qoyulması həm simptomların yaxşılaşmasına, həm də xəstənin vəziyyətinin stabilləşdirilməsi və planlaşdırılan cərrahi müdaxiləyə hazırlaşdırılması üçün tələb olunan vaxt qazandırmış olur. Bununla yanaşı qazanılmış vaxt ərzində xəstənin vəziyyətinin daha ətraflı müayinəsi, yanaşı xəstəliklərin qiymətləndirilməsi və müalicəsi, xərçəng xəstəliyinin mərhələsinin müəyyən edilməsi, habelə, məsələn, rektal xərçəng hallarında, neoadyuvant terapiyanın başlanması da mümkün olur. Beləliklə, kolorektal stentlərin qoyulması cərrahi müdaxiləyə bir növ keçid rolunu oynayır (Eng. "bridge to surgery").

Stentlərin qoyulmasında sonrakı dövrdə cərrahi rezeksiyanın aparılması mümkün olmadıqda və ya xəstə cərrahi əməliyyatdan imtina etdikdə, yoğun bağırsağa qoyulmuş stentlər qeyri-müəyyən müddət ərzində orada saxlanıla bilər. $\mathrm{Bu}$ isə daimi kolostomaya olan ehtiyacı aradan qaldırmış olur.

\section{Yoğun bağırsaq stentləri paliativ terapiya kimi.}

Maliqnant kolon obstruksiyası olan və cərrahi əməliyyata götürülməsi mümkün olmayan xəstələrin müalicəsində yoğun bağırsaq stentləri çox effektiv paliativ prosedur hesab edilir. Aparılmış bir neçə ümumileşdirilmiş icmallardan məlum olmuşdur ki, paliativ prosedur kimi istifadə edilən kolorektal stentlərin qoyulması yaxşı nəticələr verir və $90-93 \%$ hallarda obstruksiyanın tam aradan qaldırımasını təmin edir. Kolorektal stentlərin qoyulmasından sonra təkrar obstruksiya $12-16 \%$ hallarda müşahidə edilir. Cərrahi müdaxilə ilə müqayisədə kolorektal stent almış xəstələrdə ağırlaşmalar daha az baş verir, onların hospitalizasiya müddəti daha az olur, kolostomiyanın çıxarılmasına ehtiyac aradan qalxır, kimya terapiyasının daha tez başlanması mümkün olur və mortalite də azalmış olur.

Buna görə də, cərrahi müdaxilənin aparılması çox yüksək ölüm və ya xəstələnmə riski ilə əlaqəli olan xəstələrdə maliqnant kolon obstruksiyasının aradan qaldırıması üçün paliativ prosedur kimi məhz endoskopik yolla metal stentlərin tətbiqinə daha çox üstünlük verilir.

Bununla yanaşı qeyd edilməlidir ki, sol tərəfli iV mərhələ yoğun bağırsaq kanserində stentlərin qoyulması daha çox ağırlaşmalara səbəb olmuşdur. Həmçinin, yoğun bağırsaq stentlərinin aşağı rektal törəmələrdə (anal dəlikdə $<5$ sm-dən az məsafədə yerləşən), nəcisi saxlaya bilməmə olan xəstələrdə qoyulması tövsiyə edilmir.

\section{Biblioqrafiya.}

1. PDQ Adult Treatment Editorial Board. Colon Cancer Treatment-Health Professional Version.

National Cancer Institute. Available at http://www.cancer.gov/types/colorectal/hp/colon -treatment-pdq. February 27, 2017; Accessed: March 1, 2017.

2. Goldberg RM, Sargent DJ, Morton RF, et al. A randomized controlled trial of fluorouracil plus leucovorin, irinotecan, and oxaliplatin combinations in patients with previously untreated metastatic colorectal cancer. J Clin Oncol. 2004 Jan 1. 22(1):23-30.

3. Haller DG, Catalano PJ, Macdonald JS, O'Rourke MA, Frontiera MS, Jackson DV. Phase III study of fluorouracil, leucovorin, and levamisole in high-risk stage II and III colon cancer: final report of Intergroup 0089. J Clin Oncol. 2005 Dec 1. 23(34):8671-8.

4. Hurwitz H, Fehrenbacher L, Novotny W, et al. Bevacizumab plus irinotecan, fluorouracil, and leucovorin for metastatic colorectal cancer. N Engl J Med. 2004 Jun 3. 350(23):2335-42.

5. [Guideline] Desch CE, Benson AB 3rd, Somerfield MR, et al. Colorectal cancer surveillance: 2005 update of an American Society of Clinical Oncology practice guideline. J Clin Oncol. 2005 Nov 20. 23(33):8512-9.

6. Sanoff HK, Sargent DJ, Campbell ME, et al. Five-year data and prognostic factor analysis of oxaliplatin and irinotecan combinations for 
advanced colorectal cancer: N9741. J Clin Oncol. 2008 Dec 10. 26(35):5721-7.

7. Chu, E and DeVita VT. Physicians' cancer chemotherapy drug manual. Jones and Bartlett publishers. 2008.

8. Vogelstein B, Fearon ER, Hamilton SR, Kern SE, Preisinger AC, Leppert $M$, et al. Genetic alterations during colorectal-tumor development. N Engl J Med. 1988 Sep 1. 319(9):525-32.

9. Burn J, Bishop DT, Mecklin JP, Macrae F, et al. Effect of aspirin or resistant starch on colorectal neoplasia in the Lynch syndrome. N Engl J Med. 2008 Dec 11. 359(24):2567-78.

10. Meyerhardt JA, Niedzwiecki D, Hollis D, et al. Association of dietary patterns with cancer recurrence and survival in patients with stage III colon cancer. JAMA. 2007 Aug 15. 298(7):75464.

11. Aune D, Chan DS, Lau R, et al. Dietary fibre, whole grains, and risk of colorectal cancer: systematic review and dose-response metaanalysis of prospective studies. BMJ. $2011 \mathrm{Nov}$ 10. 343:d6617. [Full Text].

12. Pala V, Sieri S, Berrino F, et al. Yogurt consumption and risk of colorectal cancer in the Italian European prospective investigation into cancer and nutrition cohort. Int J Cancer. 2011 Dec 1. 129(11):2712-9.

13. Tsoi KK, Pau CY, Wu WK, Chan FK, Griffiths S, Sung JJ. Cigarette smoking and the risk of colorectal cancer: a meta-analysis of prospective cohort studies. Clin Gastroenterol Hepatol. 2009 Jun. 7(6):682-688.e1-5.

14. Cho E, Lee JE, Rimm EB, Fuchs CS, Giovannucci EL. Alcohol consumption and the risk of colon cancer by family history of colorectal cancer. Am J Clin Nutr. 2012 Feb. 95(2):413-9. [Full Text].

15. Yuhara H, Steinmaus C, Cohen SE, Corley DA, Tei Y, Buffler PA. Is diabetes mellitus an independent risk factor for colon cancer and rectal cancer?. Am J Gastroenterol. 2011 Nov. 106(11):1911-21; quiz 1922.

16. Jacobs ET, Ahnen DJ, Ashbeck EL, Baron JA, Greenberg ER, Lance $P$, et al. Association between body mass index and colorectal neoplasia at follow-up colonoscopy: a pooling study. Am J Epidemiol. 2009 Mar 15. 169(6):657-66.

17. Morikawa T, Kuchiba A, Lochhead $P$, et al. Prospective Analysis of Body Mass Index, Physical Activity, and Colorectal Cancer Risk Associated with ß-Catenin (CTNNB1) Status. Cancer Res. 2013 Mar 1. 73(5):1600-10. [Full Text].
18. Siegel RL, Miller KD, Jemal A. Cancer Statistics, 2017. CA Cancer J Clin. 2017 Jan. 67 (1):7-30. [Full Text].

19. World Health Organization, International Agency for Research on Cancer. Colorectal Cancer: Estimated Cancer Incidence, Mortality and Prevalence Worldwide in 2012. International Agency for Research on Cancer. Available at http://globocan.iarc.fr/Pages/fact_sheets_cance r.aspx. Accessed: March 1, 2017.

20. DeSantis CE, Siegel RL, Sauer AG, Miller KD, Fedewa SA, Alcaraz KI, et al. Cancer statistics for African Americans, 2016: Progress and opportunities in reducing racial disparities. CA Cancer J Clin. 2016 Jul. 66 (4):290-308. [Full Text].

21. [Guideline] American Society for Clinical Pathology, the College of American Pathologists, the Association for Molecular Pathology, and the American Society of Clinical Oncology. Guideline on the Evaluation of Molecular Markersfor Colorectal Cancer Expert Panel Draft Recommendations Summary for Open Comment Period. Available at http://www.amp.org/committees/clinical_practic e/documents/20150327CRCMMDraftRecomme ndationsforOCP-UPDATEDfinaldraft_001.pdf. Accessed: May 13, 2015.

22. Nelson R. New guidelines on colorectal cancer molecular testing. Medscape Medical News. Available at http://www.medscape.com/viewarticle/842496. Accessed: May 13, 2015.

23. Greene FL, Page DL, Fleming ID, et al. Cancer staging manual. 6th ed. New York: Springer; 2002.

24. Ogino S, Kawasaki T, Kirkner GJ, Ohnishi M, Fuchs CS. 18q loss of heterozygosity in microsatellite stable colorectal cancer is correlated with $\mathrm{CpG}$ island methylator phenotype-negative (CIMP-0) and inversely with CIMP-low and CIMP-high. BMC Cancer. 2007 May 2. 7:72.

25. Jimeno A, Messersmith WA, Hirsch FR, Franklin WA, Eckhardt SG. KRAS Mutations and Sensitivity to Epidermal Growth Factor Receptor Inhibitors in Colorectal Cancer: Practical Application of Patient Selection. J Clin Oncol. 2009 Jan 5.

26. Quasar Collaborative Group, Gray R, Barnwell $\mathrm{J}$, et al. Adjuvant chemotherapy versus observation in patients with colorectal cancer: a randomised study. Lancet. 2007 Dec 15. 370(9604):2020-9. 